\title{
WATER CONSUMPTION FOR COW WATERING UNDER LOOSE HOUSING SYSTEM
}

\author{
Valerii Vtoryi, Sergei Vtoryi, Vladislav Gordeev, Victor Khazanov, Roman Ilin \\ Federal Scientific Agroengineering Centre VIM, Russia \\ vvtoryj@yandex.ru
}

\begin{abstract}
One of the factors contributing to higher milk productivity and good health of cows is sufficient and reliable round-the-clock water supply. Scarce water consumption leads to irreversible processes in the animal body, up to its death. The aim of this study was to measure the drinking water consumption in the loose housing system of cows with consideration of the time of day, the milk yield and the indoor barn climate. The study was conducted in August-November 2019 in a cow barn with the loose housing system. The inside climate was maintained by a natural ventilation system through the light ridge on the roof and by adjustable systems inflatable membranes on the windows and air blowers installed inside the barn. The group of animals consisted of 80 Holstein cows with the productivity of 10000 to $12000 \mathrm{~kg}$ of milk per head per lactation period. During the study, the average drinking water consumption was $1.99 \pm 0.261 \cdot \mathrm{l}^{-1}$ of milk. Near the waterers, the air temperature ranged from $+2.7{ }^{\circ} \mathrm{C}$ to $+20.8^{\circ} \mathrm{C}$, with the relative humidity being $78.4-100 \%$. The maximum average water consumption of 6.51 head $^{-1} \cdot$ hour $^{-1}$ was registered after the evening milking, the minimum of 0.8 1.head ${ }^{-1}$.hour ${ }^{-1}$ was observed during the morning feeding. The water consumption increased in the first hour after the afternoon and evening milkings by $40-45 \%$ that was associated with the water balance restoration in the animals' body. The study revealed the dependences of the drinking water consumption on the milk yield and the temperature and humidity conditions in the barn; graphical and mathematical models were constructed. This study is required to create a comprehensive model for the optimal drinking water supply of cows on dairy farms under reasonable energy and water inputs.
\end{abstract}

Keywords: cow, waterer, livestock watering, milking, inside climate.

\section{Introduction}

Drinking water is an essential nutrient for life and welfare of farm animals. At the same time, it is an increasingly expensive resource that significantly affects the prime cost of milk and meat production. Therefore, rational drinking water management on farms is an important economic component. Improved housing systems and feeding practices of cows, higher productivity and weight of animals, and other factors contribute to the changes in water intake. In this regard, research is needed to update the rates of water consumption in livestock farming.

A modern farm is a high-tech production facility, where strict water consumption control and recording will reduce the feed and energy inputs and lower the anthropogenic pressure on the environment. Providing animals with water of established quality in sufficient quantities will increase their productivity by $10-15 \%$ and cut down the feed inputs by $3-5 \%[1 ; 2]$.

This factor is important for the normal physiological state of animals as it affects the travelling of nutrients through the animal's body to different organs and the excretion of harmful or unnecessary metabolic products. The water consumption of cows depends on their mass, milk yield, dry matter intake, temperature and relative humidity of the environment. Availability of water in the feed also plays an important role [3]. A cow drinks most of the water in the daytime. According to [4], the watering rates in different housing systems varied over the time intervals: cows drank $33.9 \%$ of the total daily water intake between 09:00 and 15:00, 40.0\% - between 15:00 and 21:00, and 26.1\% between 21:00 and 09:00.

Some sources indicate that cows can drink from 30 to 50 per cent of daily water consumption in the first two hours after milking [3-5], noting that to produce one litre of milk, the cow will need four litres of water average supplied through the watering system and with the feed [6].

Drinking water supply limitations result in the irreversible processes in the animal body, even its death. The water with the temperature below $+5^{\circ} \mathrm{C}$ significantly reduces the potential milk yield, and that of above $+18^{\circ} \mathrm{C}$ has a poorer taste and satisfies thirst worse. Several researchers note that the optimal temperature of the drinking water for cows is in the range from $+10^{\circ} \mathrm{C}$ to $+12{ }^{\circ} \mathrm{C}$. In this case, the animals consume the maximum amount of water and spend the feed energy on producing milk and not on heating the water to body temperature [7-12].

Deviation of the barn temperature and relative humidity from normal values also affects the water consumption and this, in turn, affects the productivity and health of animals [13; 14]. In addition, the 
time of day, the milking and feeding schedules can have a significant effect on the amount of water consumed.

The study aim was to determine the drinking water inputs under the loose housing system of cows, depending on the time of day, milk yield and the inside climate.

This is a part of research to develop a mathematical model of a dairy farm water supply system based on "animal-environment-machine" principle. A complex process of the system management requires continuous monitoring of parameters and operating modes of equipment associated with water preparation, supply and recording, as well as direct control over other systems and parameters affecting the water consumption [15].

\section{Materials and methods}

The study took place in August-November 2019, in a cow barn for 320 head with the loosehousing system. A group of 80 Holstein cows with the target milk yield of 10000 to $12000 \mathrm{~kg} \cdot \mathrm{head}^{-1}$ for the entire lactation period was selected to determine the required indicators. The cows were on the first lactation period - from the $14^{\text {th }}$ to $100^{\text {th }}$ day. The milk yield and the drinking water consumption were recorded for the whole group.

In the study, the experimental data on hourly water consumption in the cow group, the temperature and relative humidity of the indoor air were determined. The study also took into account the daily milk yield, formed from three milkings - morning, afternoon, and evening, and the external weather conditions, with the data received from the state weather station located at a distance of $12 \mathrm{~km}$ from the cow barn.

In the cow barn there were two Miraco 6301 automatic group waterers made of durable plastic with a length of $3.66 \mathrm{~m}$ and a capacity of 416 litres each (Fig. 1).

The main source of water on the farm is an artesian well more than 150 meters deep, with the water temperature being from $+5^{\circ} \mathrm{C}$ to $+6^{\circ} \mathrm{C}$. The water is pumped through the pipes to the cow barn. The water temperature in the waterers ranged from $+5.4^{\circ} \mathrm{C}$ to $+13.2^{\circ} \mathrm{C}$ for the entire study period, with an average daily air temperature in the barn being from $+2.7^{\circ} \mathrm{C}$ to $+20.8^{\circ} \mathrm{C}$.
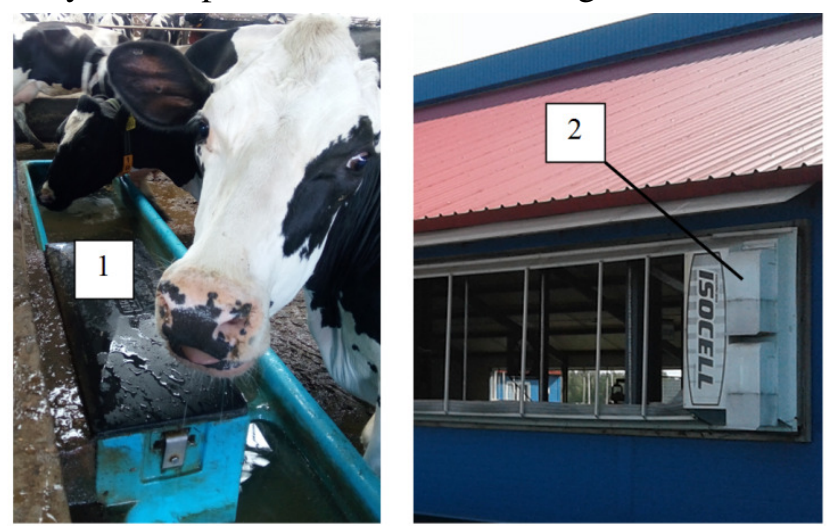

Fig. 1. Drinking equipment and inside climate control device:

1 - Miraco group waterer; 2 - IsoCell inflatable curtains

The cow barn had a natural ventilation system through the light ridge on the roof and adjustable systems, such as IsoCell inflatable curtains (Fig. 1) on the windows and pressure fans located inside the barn.

The temperature and relative humidity in the cow barn was measured in real-time mode using the recorder unit (Fig. 2) located directly above the stalls at a height of 2.0 meters. The recorder unit included the temperature sensors with a measuring range from $-40{ }^{\circ} \mathrm{C}$ to $+80^{\circ} \mathrm{C}$ and a measurement error of $\pm 0.5^{\circ} \mathrm{C}$, and relative humidity sensors with a measuring range from 0 to $100 \%$ and a measurement error of $\pm 3 \%$. The sensors were scanned and the readings were recorded every $10 \mathrm{~min}$.

Water was supplied to the waterers through a metering unit - an electronic flow meter DU-15 (Fig. 2). The flow meter was designed for continuous round-the-clock operation at an ambient temperature from $-40{ }^{\circ} \mathrm{C}$ to $+90^{\circ} \mathrm{C}$. It was a pulse type sensor with the pulse weight of 1 impulse per 
0.018 litres. The water consumption was recorded every hour during the day, separately for each waterer.
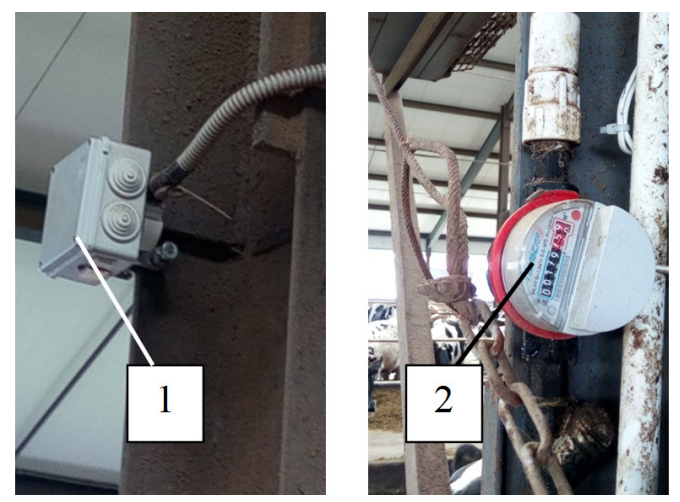

Fig. 2. Equipment for inside climate parameter recording and water consumption: 1 - inside climate parameter recorder; 2 - electronic flow meter DU-15

The daily milk yield was recorded for three milkings: in the morning, afternoon, and evening, using the milk meters installed on the milking equipment. The milking system had electronic recording of process indicators, such as the milk yield per group, milking time, number of animals in the group, etc. These indicators arrived at the central server of the farm and were included in the database. The feed mixture was distributed to the feed table with a distributor-mixer once a day at 08-00 a.m. During the study the diet composition and its moisture content did not change.

The study results were analysed by standard methods of mathematical statistics; the average values and standard deviations for the parameters and indicators under consideration were calculated [16].

\section{Results and discussion}

Fig. 3 shows the average hourly water intake of one cow in November 2019: in the time interval from 00-00 to 07-00 a.m. it was 3.1 1.head ${ }^{-1} \cdot$ hour $^{-1}$, from 8-00 to 15-00 it was 3.4 1.head ${ }^{-1} \cdot$ hour $^{-1}$, and from 16-00 to 23-00 it reached $4.11 \cdot \mathrm{head}^{-1} \cdot \mathrm{hour}^{-1}$. The maximum average water consumption of $6.51 \cdot$ head $^{-1} \cdot$ hour $^{-1}$ was registered after the evening milking. The minimum water consumption of $0.8 \mathrm{l} \cdot$ head $^{-1} \cdot$ hour $^{-1}$ was registered during the morning feeding. Such a pattern was observed during the entire study period.

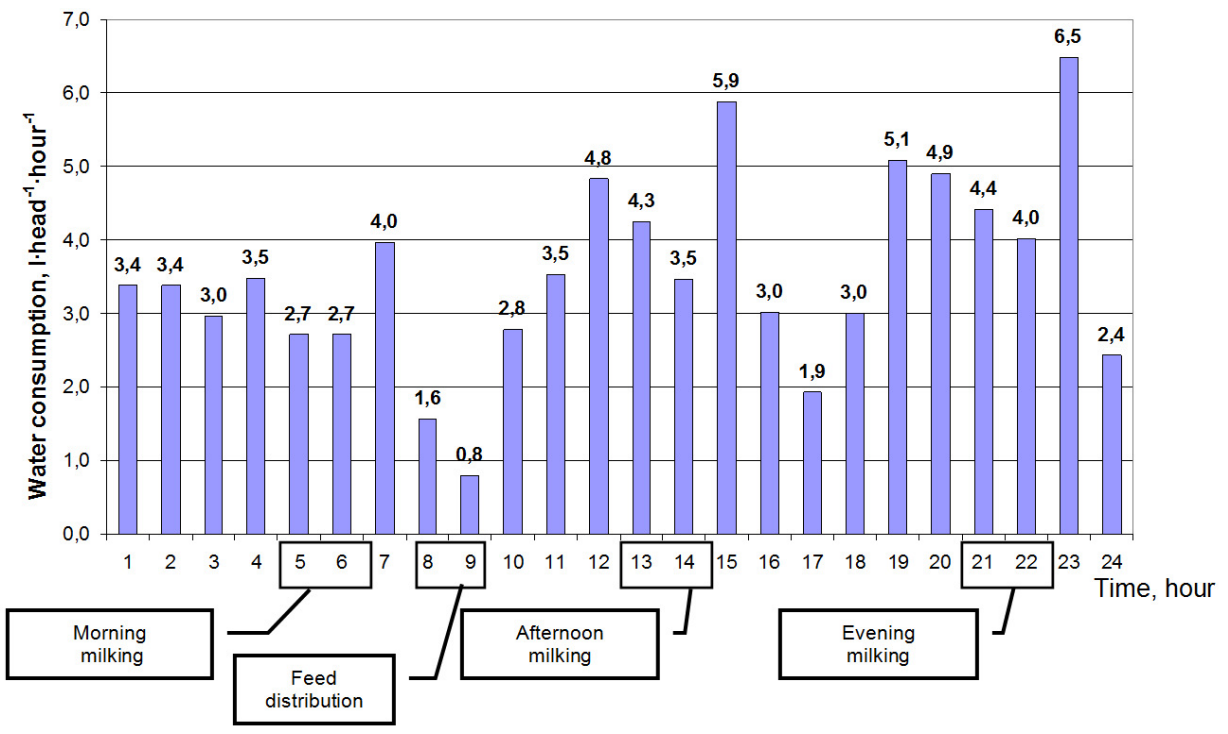

Fig. 3. Bar graph of the average hourly water intake of one cow in November 2019

When analysing the water consumption, the temperature and humidity conditions in the cow barn were considered. The monitoring results of changes in the indoor and outdoor air temperature are presented in Fig. 4. 


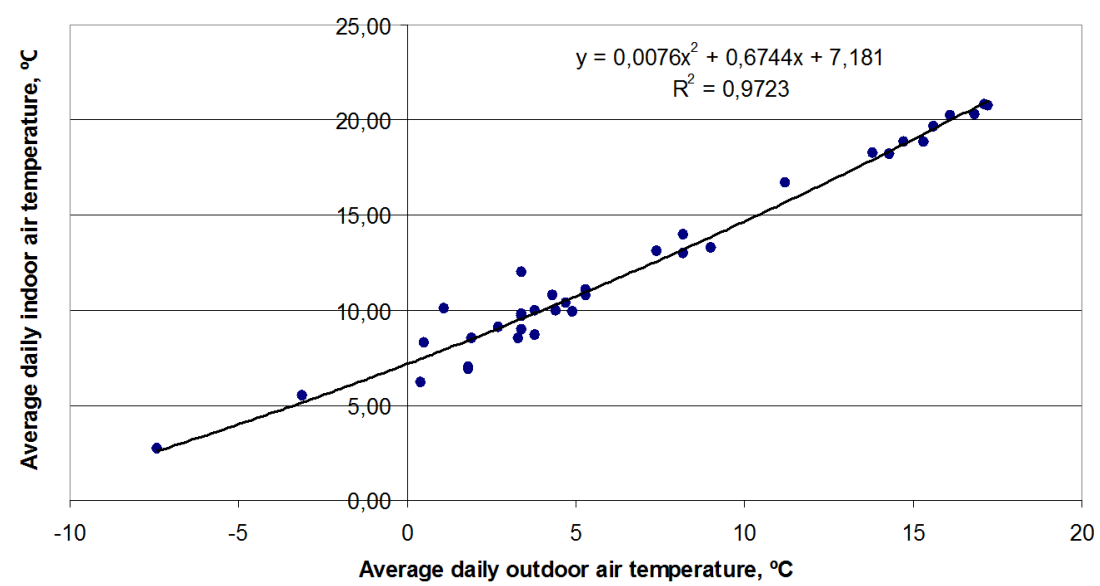

Fig. 4. Dependence of the average daily indoor temperature on the average daily outdoor temperature from August to November 2019

As can be seen from Fig. 4, the inside climate in the cow barn was closely related to the outdoor climate and depended on the control mode of the inflatable membranes on the windows. The in-barn temperature exceeded the outdoor temperature by $5-9{ }^{\circ} \mathrm{C}$. Near the waterers, the average daily air temperature was in the following range: from 10 August to 18 August - from $+18.2{ }^{\circ} \mathrm{C}$ to $+20.8{ }^{\circ} \mathrm{C}$ with an average daily relative humidity of 78.4-96.8 \%; from 23 September to 6 October - from +6.9 ${ }^{\circ} \mathrm{C}$ to $+16.7^{\circ} \mathrm{C}$ with an average daily relative humidity of $81.3-98.0 \%$; from 11 November to 23 November - from $+2.7{ }^{\circ} \mathrm{C}$ to $+11.1{ }^{\circ} \mathrm{C}$ with an average daily relative humidity of $95.9-100 \%$. It should be noted that the comfort zone in terms of temperature and relative air humidity in the premises for dairy cows is $+5.0{ }^{\circ} \mathrm{C}$ to $+15.0{ }^{\circ} \mathrm{C}$ and $40-75 \%$, respectively [11; 17]. The temperature requirements during the study period were partly observed, while the air humidity did not comply with the established standards.

In the period from 10 August to 18 August, the daily milk yield amounted to 38.9-44.7 1.head ${ }^{-1}$, with the water consumption being 1.72-2.19 $1 \cdot 1^{-1}$ of milk; from 23 September to 6 October, the daily milk yield was 42.5-45.2 $1 \cdot$ head $^{-1}$, with the water consumption being 1.8-2.02 $1 \cdot 1^{-1}$ of milk; and from 11 November to 23 November, the daily milk yield was 39.7-42.1 $1 \cdot$ head $^{-1}$, with the water consumption being 1.88-2.25 $1 \cdot 1^{-1}$ of milk. The average water consumption through a waterer of one cow to produce one liter of milk for the entire study period was $1.99 \pm 0.261$. Fig. 5 shows the relationship between the cow productivity and water consumption. At the cow productivity from 39 to $411 \cdot$ head $^{-1} \cdot$ day $^{-1}$, the water consumption grew; the further increase in the productivity resulted in the decrease of the specific per head water consumption. The determination coefficient $R^{2}=0.5846$ shows a significant relationship between the dependent and independent variables. However, it is not high enough. Therefore, some additional factors influence water consumption.

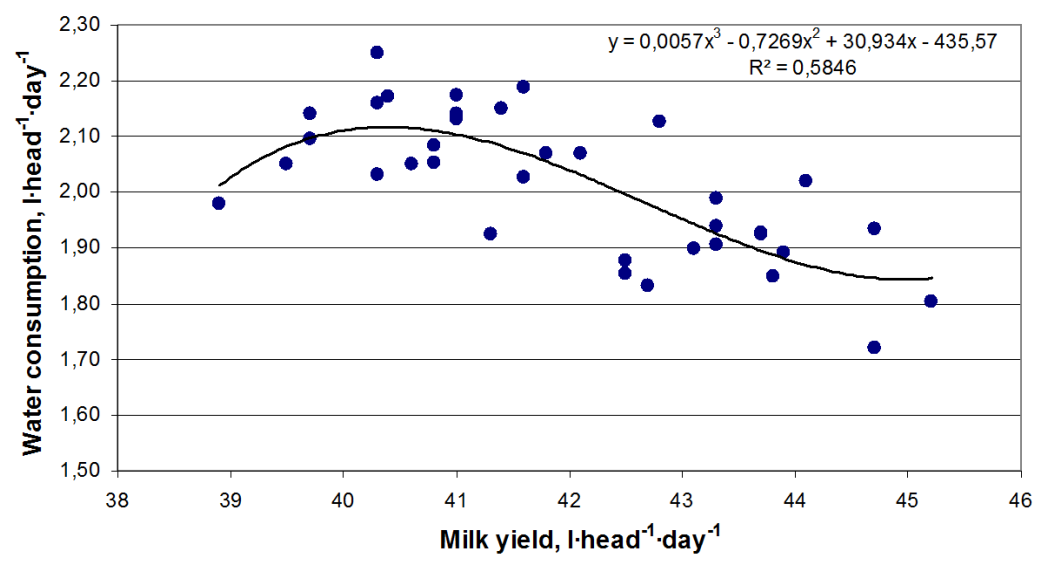

Fig. 5. Relationship between per head daily milk yield and per head daily water consumption from August to November 2019 
Figs. 6-8 show the graphical dependencies of per cow daily water consumption on the average daily indoor air temperature.

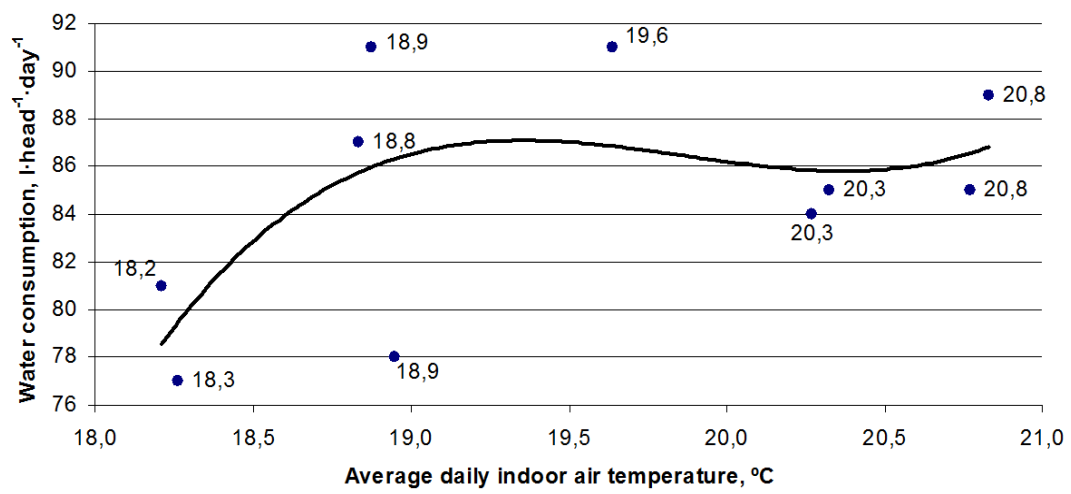

Fig. 6. Dependence of per cow daily water consumption on the indoor air temperature from 10 August to 18 August 2019

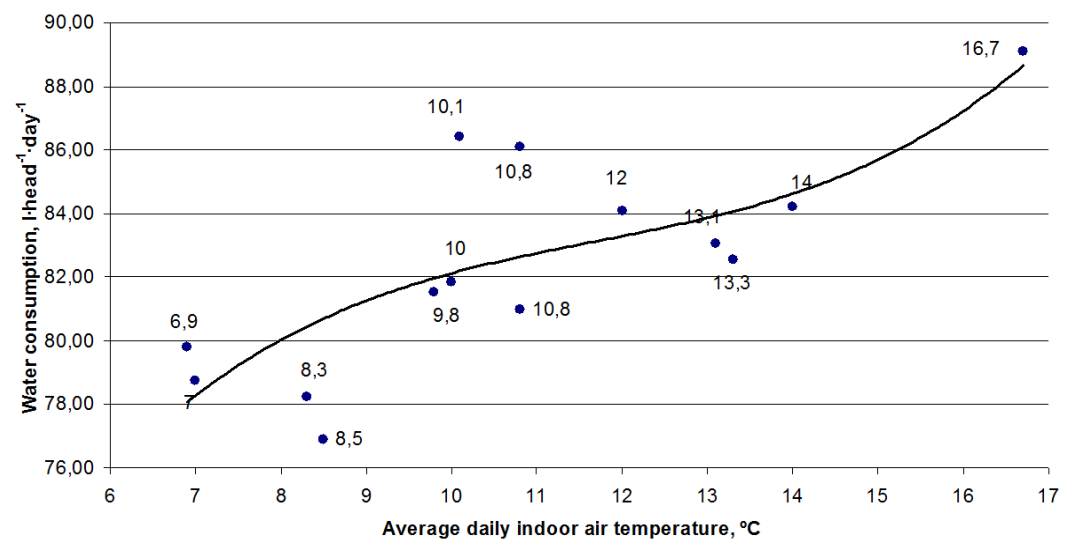

Fig. 7. Dependence of per cow daily water consumption on the indoor air temperature from 23 September to 6 October 2019

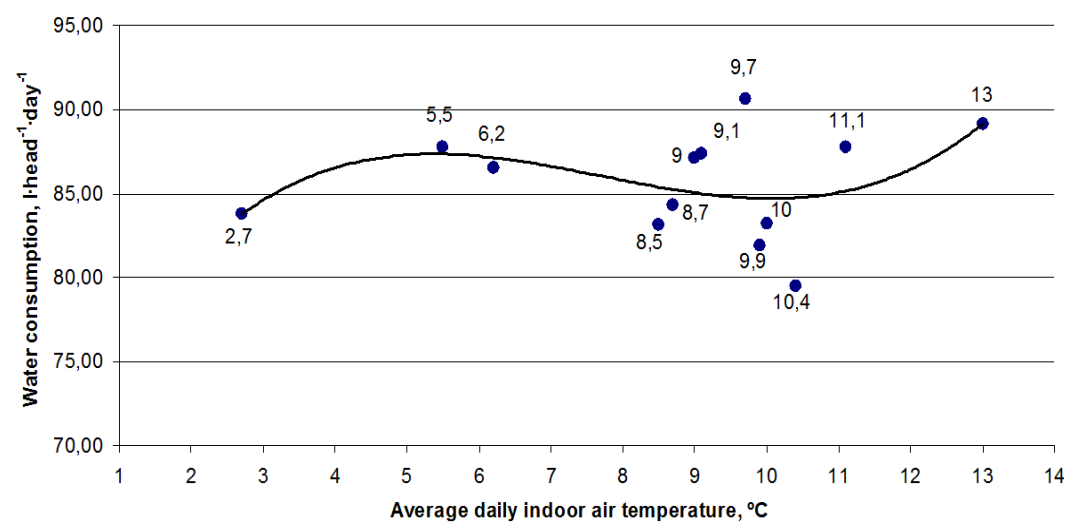

Fig. 8. Dependence of per cow daily water consumption on the indoor air temperature from 11 November to 23 November 2019

The statistical analyses of the obtained data resulted in the regression equations for the dependence of per head daily water consumption on the air temperature in the barn:

- From 10 August to 18 August

$$
P=2.441 \cdot T^{3}-145.47 \cdot T^{2}+2887.7 \cdot T-19008, R^{2}=0.384,
$$


where $P$ - water consumption, $1 \cdot$ head $^{-1} \cdot$ day $^{-1}$;

$T$ - indoor air temperature, ${ }^{\circ} \mathrm{C}$;

$R^{2}$ - determination coefficient.

- From 23 September to 6 October

$$
P=0.023 \cdot T^{3}-0.805 \cdot T^{2}+9.944 \cdot T+40.25, R^{2}=0.609,
$$

- From 11 November to 23 November

$$
P=0.0517 \cdot T^{3}-1.197 \cdot T^{2}+8.39 \cdot T+68.82, R^{2}=0.212 .
$$

The determination coefficient $R^{2}$ of equation (1) 0.384 and equation (3) 0.212 shows an insignificant relationship between the dependent and independent variables in the equation, compared with equation (2), where $R^{2}=0.609$. This confirms the influence of additional unaccounted factors on the water consumption during these periods.

\section{Conclusions}

According to the study results, the milking schedule significantly affected the level of water consumption by cows. It increased in the first hour after the afternoon and evening milkings by 40$45 \%$ that was associated with the water balance restoration in the animals' body. During this time, animals need the maximum access to water in order to reduce the risks of associated stress affecting the subsequent milk production.

The temperature and relative humidity inside the barn, which are formed under the influence of the external weather conditions, are important factors affecting the water consumption by animals. The study allowed clarifying the degree of this effect, as well as the need to consider it when optimizing the process of cow watering.

The study results will be used to develop a comprehensive model for water supply of cows on dairy farms. This model will be a symbiosis of simple mathematical models for the control over technological processes aimed at increasing the cows' productivity and optimizing the energy and water inputs. The task of the follow-up studies is to include in the list of relevant affecting factors the animal weight, feeding diets and gas components of the inside air. This is expected to contribute to a more reliable integrated model.

\section{References}

[1] Гордеев В.В., Вторый С.В., Собовая С.В. Алгоритм системы управления процессом поения в коровниках (Algorithm of livestock watering control in cow barns). Technologies, machines and equipment for mechanised crop and livestock production: Технологии и технические средства механизированного производства продукции растениеводства и животноводства. 2018. No. 97. pp. 227-234. (In Russian).

[2] Семин А. Комфортная среда обитания коровы - залог хорошего здоровья и продуктивного долголетия (Comfortable habitat of a cow pledge of good health and productive longevity). Dairy Industry: Молочная промышленность. 2013. No. 7. p. 20 (In Russian).

[3] Schroeder J.W. Water Needs and Quality Guidelines for Dairy Cattle. 2015. [online] [28.04.2020] Available at: https://www.ag.ndsu.edu/publications/livestock/water-needs-and-quality-guidelinesfor-dairy-cattle

[4] Axegärd C. Individual drinking water intake of dairy cows in an AMS barn. 2017. [online] [28.04.2020] Available at: https://stud.epsilon.slu.se/10295/

[5] Cardot V., Le Roux Y., Jurjanz S. Drinking Behavior of Lactating Dairy Cows and Prediction of Their Water Intake. Journal of Dairy Science. 2008. Vol. 91, 6. DOI: https://doi.org/10.3168/jds.2007-0204 [online][28.04.2020] Available at: https://www.journalofdairyscience.org/article/S0022-0302(08)71176-7/fulltext

[6] Parker D., Brown M. Water Consumption for Livestock and Poultry Production. Encyclopedia of Water Science. 2003. DOI: 10.1081/E-EWS 120010303 [online] [28.04.2020] Available at: https://www.researchgate.net/publication/269393738_Water_consumption_for_livestock_and_po ultry_production 
[7] Бабий А. Влияние поения на удой (Effect of livestock watering on the milk yield). AgriNews: Сельскохозяйственные вести. №1, 2012. p. 46 (In Russian).

[8] Богомолов В., Головня Е. Качеству питьевой воды - повышенное внимание (Drinking water quality needs a greater attention). Compound Feed: Комбикорма. 2012. No. 6. pp. 85-86. (In Russian).

[9] Шматко Н.Н., Музыка А.А., Кирикович С.А., Москалёв А.А. Изучения организации водоснабжения на комплексе по производству говядины (Study of the water supply organization on the beef complex). Hot topics of the intensive development of animal husbandry: Актуальные проблемы интенсивного развития животноводства. 2016. №. 19 (2). pp. 276282. (In Russian).

[10]Симонов Г.А. Поение коров теплой водой в зимний период повышает молочную продуктивность (Watering of cows with warm water in winter increases the milk yields). Efficient Animal Husbandry: Эффективное животноводство. 2015. No. 10 (119). pp. 52-53. (In Russian)

[11]РД-АПК 1.10.01.01-18. Методические рекомендации по технологическому проектированию ферм и комплексов крупного рогатого скота (Management Directive for Agro-Industrial Complex. Recommendations on technological designing of cattle farms and complexes). Moscow: Rosinformagrotech: Москва: Росинформагротех. 2018. 166 p. (In Russian).

[12] Ястребова Е.А., Мартынова Е.Н. Влияние влажности воздуха на молочную продуктивность и физиологическое состояние коров в СХПК Колхоз «Колос» Вавожского района Удмуртской Республики (Influence of air humidity on dairy productivity and physiological condition of cows in the agricultural enterprise Kolkhoz "Kolos", Vavozhsky District of Udmurt Republic). Bulletin of the Izhevsk State Agricultural Academy: Вестник Ижевской государственной сельскохозяйственной академии. 2011. No. 4. pp. 39-42. (In Russian).

[13]Le Riche E., VanderZaag A., Burtt S., Lapen D., Gordon R. Water Use and Conservation on a Free-Stall Dairy Farm. Water. 2017. 9, p. 997. DOI:10.3390/w9120977 [online][29.02.2020] Available at:

https://www.researchgate.net/publication/321840700_Water_Use_and_Conservation_on_a_FreeStall_Dairy_Farm

[14] Krauß M., Drastig K., Prochnow A., Rose-Meierhöfer S., Kraatz S. Drinking and Cleaning Water Use in a Dairy Cow Barn. Water. 2016. 8, 302. DOI:10.3390/w8070302 [online] [29.02.2020] Available https://www.researchgate.net/publication/305483846_Drinking_and_Cleaning_Water_Use_in_a_ Dairy_Cow_Barn

[15]Гордеев В.В., Вторый С.В., Хазанов В.Е., Ильин Р.М. Анализ организации водообеспечения коров летом при беспривязном содержании (Organization of summer water supply of cows under the loose housing system). Technologies, machines and equipment for mechanised crop and livestock production: Технологии и технические средства механизированного производства продукции растениеводства и животноводства. 2019. №. 100. pp. 146-152. (In Russian)

[16]Валге A.M. Использование систем Excel и Mathcad при проведении исследований по механизации сельскохозяйственного производства (Application of Excel and Mathcad in investigations associated with mechanisation of agricultural production). Saint Petersburg: SZNIIMESH Rosselkhzacademii: СПб: ГНУ СЗНИИМЭСХ Россельхозакадемии. 2013. 200 p. (In Russian)

[17] Vtoryi V., Vtoryi S., Ylyin R. Investigations of temperature and humidity conditions in barn in winter. Proceedings of 17 th International Scientific Conference "Engineering for Rural Development" May 23-25, 2018, Jelgava, Latvia. pp. 265-269. 